\title{
An Analysis of Gender Stereotyping in English Teaching Course Books
}

$$
\text { Meral ŞEKER }^{a^{*}} \text {, Ayça DiNÇER }{ }^{a}
$$

${ }^{a}$ Çukurova University, School of Foreign Languages, Adana/Turkey

\begin{tabular}{l}
\hline Article Info \\
\hline DOI: 10.14812/cufej.2014.007 \\
\hline Article history: \\
Received $\quad 01$ June 2013 \\
Revised $\quad$ 30 December 2013 \\
Accepted $\quad$ 04 February 2014 \\
\hline Keywords: \\
Gender stereotyping, \\
Gender identity, \\
Foreign language learning. \\
\end{tabular}

\begin{abstract}
Learners who are exposed to a new and different culture in the context of foreign language learning are viewed as reflective agents in the continuous process of identity reformation (Pavlenko and Lantolf, 2000). Course books, which are one of the main sources of target language and culture input, have a great impact in the formation of pragmatic competence and the development of relational identity. However, in the process of cultural transfer throughout course books in foreign language learning, the imposition of gender stereotyping may accompany other pragmatic traits of the target culture and interfere with the formation of relational identity. In this respect, the aim of this study is to identify implicit indications of gender role stereotyping in English teaching course books texts used for Turkish learners. The data gathered from four widely used English language course books and was analyzed using detailed textual analysis (Fairclough, 2003) so as to identify and categorize stereotyped roles for females and males. The findings depict the implicit gender roles in course books and outline the relationship between the elements of linguistic features of texts and the way they function in reinforcing gender stereotyping.
\end{abstract}

\section{Introduction}

The need for a more social and critical linguistics which focuses on language use and language as action and communication in social and cultural contexts was one of the main factors in the emergence of pragmatics. Unlike Chomskyan linguistic view, pragmatic point of view perceives language as situated in relation to its users who are "more than producers of linguistic forms"(Duranti, 2001, p.5). Pragmatics addresses language users from a broad perspective including specific societal factors such as schools, families, which are considered to have fundamental impact on the speakers. Languages are created by human interaction, and thus should be referred in relation to its users' contexts (Mey, 2001; Delen and Tavil, 2010). These social and cultural contexts of use are not static but dynamic and meshed in the continually changing surroundings where speakers live and interact (Mey, 2001).

Situating language in its users' contexts encompasses the forms of language and the forms associated with the dominant and, at the same time, subordinate social categories. Philips (2004) emphasizes the creation and reproduction of inequality through language. The author suggests four key areas in this development: "language use and the regulations of turns in bureaucratic settings, including classrooms, courtrooms, clinics; gender and language, with a focus on the inequalities created through men's greater involvement in public genres of discourse; language and political economy and inequalities created by lack of prestige amongst the economically disadvantaged; language and colonialism and the impact of colonial cultural systems on the language and the culture of the colonized" (p.476).

\footnotetext{
*Corresponding author:sekerm@cu.edu.tr
} 


\section{Literature Review}

\section{The reflection of gender identity}

Gender identity, as one of the components of individual identity, determines 'female' roles for women and 'male' roles for men. These roles constitute the behaviors, attitudes, interests and skills that a culture considers appropriate for males and females. Like the other features of identity, gender identity and the roles it attaches to individuals are not stable but dynamic. The interference by every culture to assign particular traits to these dynamic roles is referred to as 'gender stereotyping' (Mkuchu, 2004). The assumption underlying stereotyping is that the associated attributes of men apply to all men and those of women apply to all women. This female-male differentiation is the result of both environmental influences and the identity, concepts, preferences, skills, personal attitudes and behaviors individuals develop starting from their childhood consistent with the definitions of genders in the individual's culture (Arslan, 2000).

The images of male and female identities in societies are shaped and reflected frequently by the help of media, education, traditions, norms and other societal regulations (Coates, 1986). As de Beavoir (1953) emphasizes, people are not born as women but they are raised as women. Although there are relative differences among cultures in respect to gender equality and its reflections in societal regulations, researchers mostly agree that males are attributed predominant roles compared to females in almost all cultures.

Research in the field of discourse has revealed many examples of this inequality (e.g. Coates, 1986; Helinger \& Bussmann, 2001; Poulou, 1997). For instance, the study conducted by Akünal (1998) ideology in media discourse indicated that media presents the image of women as having subservient status when compared to the image of men. Compiling and analyzing samples of television advertisements based on critical discourse analysis, the researcher concludes that the women are reflected as having certain, traditional stereotypes with an image that has subservient roles, such as looking after children and husbands, cooking, or tidying up and that these images are reinforced by the media by producing and underlining the role-appropriate behaviors tailored to women in the society.

\section{Gender stereotyping in Turkish language}

Language is commonly viewed as the symptom of social inequality rather than being the reason for such inequality. Genders are attributed specific roles within cultures and these roles are maintained, shaped and transferred through language. As any other language, Turkish language conveys the reflection of gender stereotyping. The dictionary published by official Turkish Language Institution reveals the stereotypes tailored to males and females in Turkish culture. The study conducted by Cubukcu, Esme and Ilerten (2009) attempted to analyze how the images of female and male population are reflected by lexemes used in Essential Turkish Dictionary (TDK, 2005). Scanning the lexemes that directly portray female and male population, it was indicated that the Essential Turkish Dictionary reflects males predominant over females both quantitatively and qualitatively regarding social status, sexuality, physical appearance and reproduction.

\section{Gender stereotyping and foreign language learning}

As one of the most influential device in the imposition of the normative expectations of a society, education aids each generation to take over the process of cultural accumulation from where the previous generation has left (Tasmajian, 2000). In the process of transferring the cultural heritage, it also serves the imposition of gender stereotyping, which is well noted in the literature to have negative effects on individuals (see Arslan, 2000; Davies, 1995; Esen \& Bağlı, 2002; Helvacıoğlu, 1996; Michel, 1986). When exposed to a different society's norms and stereotypes through language learning, learners' identity is reshaped under the gender role representations presented in course books and the 
instruction they receive (Helvacıoğlu, 1996). Since gender stereotyping in education perpetuates and reinforces the existing inequality between males and females both in the schooling system and in the community at large, the elimination of gender stereotyped messages is vital.

Theories of foreign language pragmatic learning suggest that learners need to be provided with sufficient input to become pragmatically competent and to acquire "the ability to understand and produce socio-pragmatic meaning with pragma-linguistic conventions" (Kasper \& Rose, 2002, p. 318). Delen and Tavil (2010) refer to this ability as 'pragmatic competence'. Without this competence, learners who are fully competent of producing grammatically correct sentences may end up with pragmatically inappropriate utterances causing breakdowns in communication (Bardovi-Harlig \& Dörnyei, 1998; Bardovi-Harlig \& Hartford, 1996). Thus, learners should be provided a learning environment where they can experience the functions in context and acquire pragmatic competence

Teaching pragmatic competence effectively in second language learning environment can be achieved by exposing the learners to relevant input features in appropriate amount and type (Schmidt, 2001). This necessitates learners attentive involvement "to the action that is being accomplished, the linguistic, paralinguistic and non-verbal forms by which the action is implemented, its immediate interactional or textual context, and the dimensions of the situational context that are indexed by linguistic and pragmatic choices"(Kasper \& Roever, 2005, p. 318). When such a teaching environment is provided, learners can develop pragmatic and sociolinguistic knowledge and perform effective communicative action with target forms. For Blum-Kulka (1991) this is even easier for especially adult second language learners since they are already competent in one language and can draw on pragmatic universals and L1 transfer of discourse.

Throughout language learning, learners should be involved in social practices to identify the interrelationships of sociopolitical contexts and social identities (Kasper \& Rose, 2002). Brown and Levinson (1987) refers to this ability as 'socio-pragmatic competence' by which the learner acknowledges the relationships between communicative action and power, social distance and the imposition associated with a past or future event (Kasper \& Roever, 2002) as well as recognizing mutual rights and obligations and taboos (Thomas, 1983).

In foreign language learning surroundings, a great amount of the input students receive is provided by course books along with the teacher. Although many researchers claim that language teaching course books have problems regarding authenticity and coverage of important aspects, they agree on the important role they have in the formation of pragmatic competence of language learners (e.g. Delen \& Tavil, 2010; Ellis, 1994; Salazar Campillo, 2007).

Under the exposure to a new language and culture associated with it, pragmatic theories developed in second language learning research suggest that learning a foreign language affects learners' identities. They view learners who are exposed to a new and different culture via language as reflective agents in the continuous process of identity reformation (e.g. Block, 2007; Kanno, 2003; Norton, 1995; Pavlenko \& Lantolf, 2000). Boxer and Cortés-Conde (1997) argue that, in an attempt to acquire foreign language pragmatic competence, the learner develops a relational identity which refers to "participants' construction of a new identity built on their past, present, and future relationship" (p. 282). Via interaction with target language input, identity reflects an individual's relationship with the external environment through the identification with discourses and the complex and recurrent interactions between the individual and the social (Gu, 2010).

Moving from these discussions, the aim of this study is to identify indications of gender role stereotyping in the texts in English teaching course books used at the first year of university education in Turkey. The data gathered from four widely used course books was analyzed using detailed textual analysis (Fairclough, 2003) so as to identify and categorize stereotyped roles for females and males. 
Content analysis was conducted to interpret the data from texts. The findings depict the gender roles in course books and outline the relationship between the elements of linguistic features of texts and the way they function in reinforcing gender stereotyping.

\section{Method}

\section{Data Collection Procedure}

In order to find out how gender identities are reflected in English teaching course books, four books, namely 'Speak out', 'Outcomes', 'New Success' and 'Language Leader' in pre-intermediate levels, have been analyzed. As a result of systematic content analysis method, features attributed to women and men identity in all tasks in these course books are elicited and classified. As suggested by Hodkinson and Hodkinson (1999), the researchers followed "stakeholder research" model, where the data was analyzed in three steps. First, the course books were analyzed by the two researchers independently. In the second step, the findings from the preliminary analyses were cross-analyzed and evaluated by the researchers. Finally, two researchers discussed and finalized the categories emerged from the analysis.

\section{Results}

As a result of the content analysis, the findings are grouped under three main categories: (1) attributions of professions, (2) attributions of personality features, and (3) attributions of physical appearance. The results are presented in three parts respectively.

\section{Attributions of Professions}

First of all, the analysis of the data has revealed the frequencies of professions attributed to male and female population. The attributions are grouped in ten major categories as displayed in Table 1.

Table 1.

Professional Attributions for Males and Females.

\begin{tabular}{lrrrrr}
\hline & \multicolumn{3}{c}{ Female } & \multicolumn{3}{c}{ Male } & Total \\
\hline & F & \% & F & $\%$ & \\
\cline { 2 - 6 } Arts & 29 & 26.1 & 82 & 73.8 & 111 \\
Business & 23 & 44.2 & 28 & 53.8 & 52 \\
Science & 7 & 22.5 & 24 & 77.4 & 31 \\
Medicine \& Health & 7 & 28 & 18 & 72 & 25 \\
Illegal jobs & 2 & 8 & 23 & 92 & 25 \\
Media & 7 & 53.8 & 6 & 46.1 & 13 \\
Government Services & 5 & 41.6 & 7 & 58.3 & 12 \\
Politics & 2 & 22.2 & 7 & 77.7 & 9 \\
Education & 6 & 85.7 & 1 & 14.2 & 7 \\
Sports & 2 & 50 & 2 & 50 & 4 \\
Others & 8 & 40 & 12 & 60 & 20 \\
Total & 98 & 31.8 & 210 & 68.1 & 308 \\
\hline
\end{tabular}

As Table 1 shows, the most frequently profession category is arts, which is mostly used for males (73.8 \%). Business related professions are second highly used jobs with almost equal attribution frequencies for males (53.8\%) and for females (44.2\%). On the other hand, science, as the third most frequent occupational area, has significantly higher frequency for males $(77.4 \%)$. Males also have significantly higher frequency rates for medicine and health $(72 \%)$, illegal jobs (92\%) and politics (77.7 $\%)$. The professions with higher frequencies for females are related to only educational field. The results show that males and females have relatively equal attributions in the field of business, media, government services and sports. The least commonly used job for males is education (14.2\%) whereas 
for females, arts (26.1\%), science $(22.5 \%)$, medicine and health (28\%), illegal jobs (8\%) and politics $(22.2 \%)$ are less commonly used compared to males. From the analysis, it can be implied that specific fields of occupations are attributed to females (i.e. education) and some others to males (i.e. arts, science, medicine and health, illegal jobs, and politics). This can be inferred as educational jobs are more appropriate for females and less for males. At the same token, jobs related to science, arts, politics, medicine and illegal jobs are mostly possessed by males.

\section{Attributions of Personality Features}

Table 2 displays the personality features attributed to males and females. The features are grouped under five main categories: intellect, social relations, psychological state, sense of responsibility and physical strength. Each category has a sub-classification dividing the attributions into normally desired and undesired features.

As Table 2 shows, out of 266 personality features, 156 (58.6\%) of them used to refer to males and $110(41.3 \%)$ of them were used for females. The majority of all attributions used for males falls under desired sub-category (65.5\%). The highest rate for all five categories for males is social relationship (36.5\%), the majority of which were desired adjectives (66.6\%). The other high attribution for males belongs to psychological state $(25.6 \%)$ and intellect $(19.8 \%)$. While males are mostly referred to negatively in terms of psychological state $(60 \%)$, they are attributed very positive qualities regarding intellect (87\%). The references used for males in terms of sense of responsibility and physical strength are relatively lower but mostly positive (65 \% for sense of responsibility and $100 \%$ for physical strength). Males are not referred to negatively in terms of physical strength.

The results reveal lower attributions used for females ( $41.3 \%$ of all attributions) compared to those used for males. The majority of all attributions are under desired subcategory (65.4\%). The highest rates of the adjectives associated with females are under sense of responsibility (36.3\%) and secondly under social relationships (32.7\%). Positive attributions under these categories are significantly higher than the negative ones (75\% of sense of responsibility and $69.4 \%$ of social responsibility). In terms of psychological state, females are more frequently referred to using undesired adjectives (65.3\%).

There is no undesired adjectives for intellect and physical strength used for females, though the frequency of them under these categories are significantly lower than the adjectives attributed to males. Out of 37 attributions used for both genders, $83.7 \%$ of them are used for males whereas only $16.2 \%$ of them are used for females.

The overall comparison of the personality attributions used for males and females indicates that there are more attributions for males in total (58.6 \%) than females. Males are more frequently referred to in terms of intellect, social relationships and psychological state. On the other hand, females are mostly attributed personality features of sense of responsibility, social relationships and psychological state. The attributions regarding intellect and physical strength are significantly lower for females than those used for males. Also, a higher percentage of psychological state attributions are under undesired subcategory both for females (65.3\%) and for males (60\%).

To sum up, while males are represented as holding positive qualities for intellect, social relationships and physical strength, females are represented as having strong sense of responsibility and desired social relationship qualifications. 
Meral ŞEKER \& Ayça DINÇER - Çukurova University Faculty of Education Journal, 43(1), 2014, 90-98

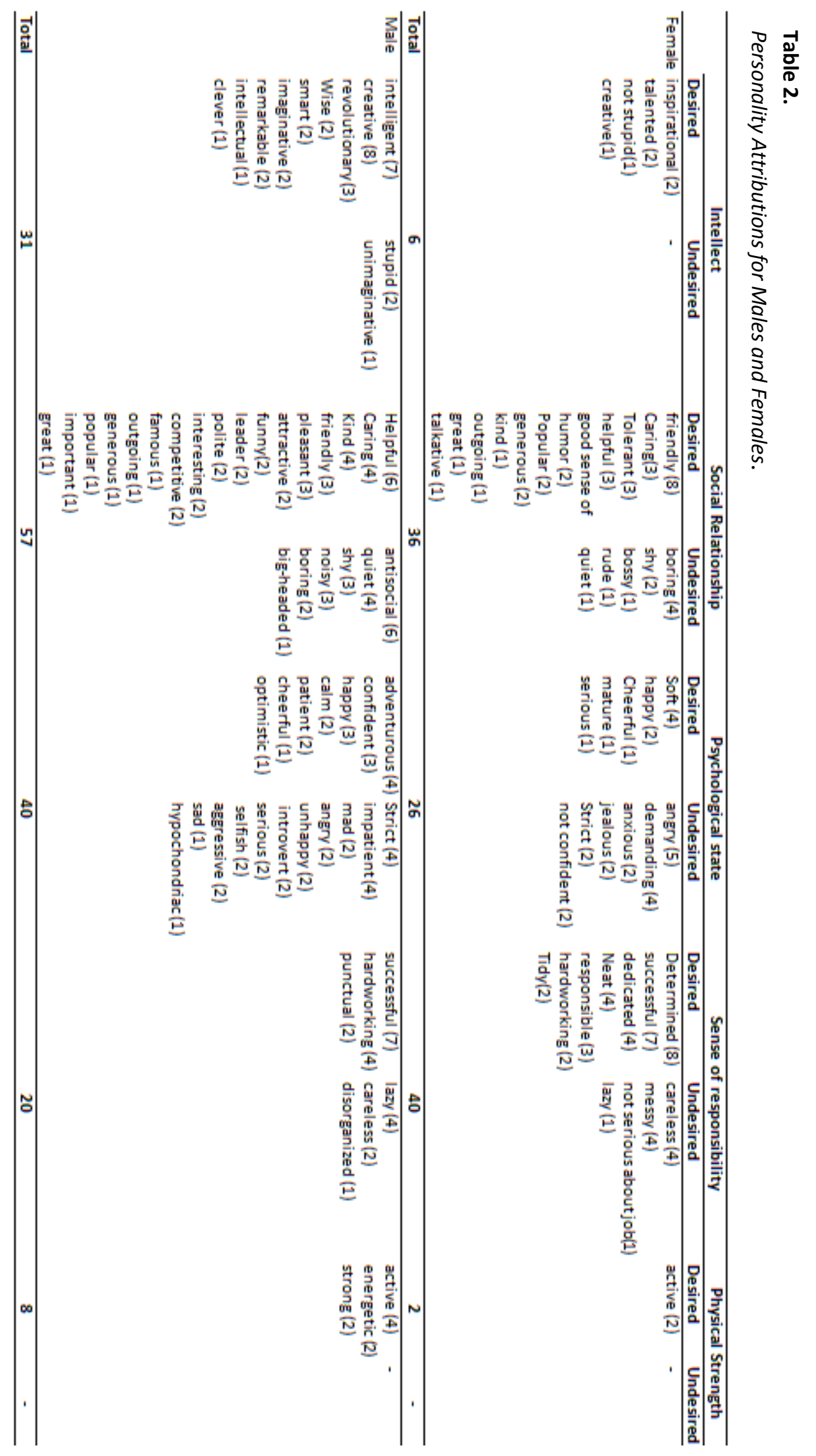




\section{Attributions of Appearance}

Another category that emerged from the analysis is physical appearance attributions. Although the number of these attributions is lower that professional and personality features, they indicate different portrayals for each gender. The findings are presented in Table 3.

Table 3.

Physical Appearance Attributions for Males and Females.

\begin{tabular}{|c|c|c|c|c|c|c|c|}
\hline & Hair & Eyes & Height & Weight & Age & Opinion & Total \\
\hline \multirow[t]{3}{*}{ Female } & Long (3) & Brown (2) & Tall (1) & Slim (2) & Young (4) & Pretty (3) & \\
\hline & Blond (3) & Green (1) & Short (2) & Middle weight (1) & & & \\
\hline & Short (1) & & & Fit (1) & & & \\
\hline Total & 7 & 3 & 3 & 4 & 4 & 3 & 24 \\
\hline \multirow[t]{6}{*}{ Male } & Short (3) & Blue (2) & Tall (5) & Overweight (1) & Young (8) & Ugly (1) & \\
\hline & Dark (1) & & & Fit (1) & & Handsome (1) & \\
\hline & & & & & & Good & \\
\hline & & & & & & looking (5) & \\
\hline & & & & & & Nicely & \\
\hline & & & & & & Dressed (1) & \\
\hline Total & 4 & 2 & 5 & 2 & 8 & 8 & 29 \\
\hline
\end{tabular}

The physical appearance attributions used for both genders are 53 in total. $54.7 \%$ of them are used for males and $45.2 \%$ of them are attributed to females. Most of the attributions for males are used for opinion and age features. As for females, the most frequent ones are hair, weight and age.

The most frequent description adjectives used for females depict a "short, slim, young and pretty woman with long blond hair and brown eyes". As for males, the depiction is a "tall, young, good-looking man with short dark hair and blue eyes". For weight, no clear specification is used for males.

Overall, the number of physical attributions for both genders is relatively lower compared to other attributions. The reason may be that course book series usually focus on more concrete physical concepts at elementary and / or beginner level, and move to more abstract and detailed descriptions on higher proficiency level books. In this level, most of the attributions used for both genders are for personality, followed by jobs and physical appearance. However, from the appearance attributions that these books contain, women and men are portrayed in a specific way via the frequency of the adjectives used for them.

\section{Discussions and Conclusion}

The study aimed to identify the attributions for males and females which implicitly reinforce gender stereotyping. The analysis revealed stereotyping in three levels. In terms of personality features, males are more frequently referred to and had higher desired qualities when compared to females. Attributions for intellect and physical strength are almost used to refer only to males. According to the results, females have mostly desired features for sense of responsibility and social relationships. On the other hand, males hold desired qualifications regarding social relationships, physical strength and intellect. Another level of gender stereotyping is found at profession related attributions. Females are sought to be only in educational occupations whereas males are frequently attributed professions in the fields of business, medicine, politics and arts. When it comes to physical appearance, females are mostly depicted as short, young, blond, and pretty while males are tall, young and good-looking.

These representations in the English course books mirror the roles tailored to both genders in the society. The findings concur with Philips's (2004) statement that males are usually represented in 
languages tacitly as having the intellectual and physical power. However, attaining gender equality in all levels of the modern life still remains to be one of the targets. Therefore, it is necessary to reveal the implications of gender stereotyping especially in educational field to be able to overcome the long maledominant gender ideology. In foreign language learning contexts, reflecting gender equality throughout texts and tasks should be one of the course book selection criteria for educators and curriculum planners. It is also important for teachers to identify such implications and neutralize them with the help of classroom instruction.

Further studies should be conducted conveying a wider range of course books and gather learners' reflections on gender stereotyping. Also, foreign language teachers' opinions and suggestions should be investigated in order to provide substantial steps toward a society where equality is reflected in all levels.

\section{References}

Akünal, Z. (1998). Dil ve cinsiyet: Reklam dili çözümlemesi. Çukurova Üniversitesi Sosyal Bilimler Dergisi, 5(5), 187-198.

Arslan, Ş. A. (2000). Ders kitaplarında cinsiyetçilik. Ankara: T.C. Başbakanlık Kadının Statüsü ve Sorunları Genel Müdürlüğü Yayınları.

Beauvoir, S. D. (1953). The second sex. London: Jonathan Cape.

Bardovi-Harlig, K. \& Doernyei, Z. (1998). Do language learners recognize pragmatic violations? Pragmatic vs. grammatical awareness in instructed L2 learning. TESOL Quarterly, 32, 233-259.

Bardovi-Harlig, K. \& Hartford, B. (1996). Input in an institutional setting. Studies of Second Language Acquisition, 18, 171-188.

Block, D. (2007). Second language identities. London: Continuum

Blum-Kulka, S. (1991). Interlanguage pragmatics: The case of requests. In R. Phillipsen, E. Kellerman, L. Selinker, M. Sharwood-Smith \& M. Swain (Eds). Foreign Language pedagogy research: A commemorative volume for Claus Faerch (pp. 255-272). Clevedon and Philadelphia: Multilingual Matters.

Boxer, D., \& Cortés-Conde, F. (1997). From bonding to biting : Conversational joking and identity display. Journal of Pragmatics, 27, 275-295.

Brown, P. \& Levinson, S. D. (1987). Politeness: Some universals in language usage. Cambridge: Cambridge University Press.

Coates, J. (1986). Women, men and language. London: Longman.

Çubukçu, H., Eşme, M. \& Ilerten F. (2009). How sexism operates in the basic Turkish Dictionary. In Communication Interculturelle et Litterature, International conference on Paradigma discursulu Ideologue,Galati, Edutura Europus, Nr.2(6).

Davies, B. (1995). Gender bias in school textbooks. London: Commonwealth Secretariat.

Duranti, A. (2001). Linguistic anthropology: A reader. Blackwell, Oxford.

Delen, B. \& Tavil, Z. M. (2010). Evaluation of four course books in terms of three speech acts: Requests, refusals and complaints. Procedia Social and Behavioral Sciences, 9, 692-697.

Ellis, R. (1994). The study of second language acquisition. Oxford: Oxford University Press.

Esen, Y. \& Bağlı, M. T. (2002). İlköğretim ders kitaplarındaki kadın ve erkek resimlerine ilişkin bir inceleme. Ankara Üniversitesi Eğitim Bilimleri Dergisi, 35, (1-2), 143-154. 
Meral ŞEKER \& Ayça DiNÇER - Çukurova University Faculty of Education Journal, 43(1), 2014, 90-98

Fairclough,N. (2003). Analyzing discourse and text: Textual analysis for social research. London: Routledge.

Gu, M. M.(2010). Identities constructed in difference: English language learners in China. Journal of Pragmatics, 42, 139-152.

Hellinger, M. \& Bußmann, H. (2001). Gender across languages: The linguistic representation of women and men. Amsterdam: John Benjamins.

Helvacıoğlu, F. (1996). Ders kitaplarinda cinsiyetçilik 1928-1995. Ankara: Kaynak Yayınları.

Hodkinson, H. \& Hodkinson, P.(1999). Teaching to learn, learning to teach? School- based non-teaching activity in an initial teacher education and training partnership scheme. Teaching and Teacher Education, 15(3), 273-285.

Kanno, Y. ( 2003). Negotiating bilingual and bicultural identities: Japanese returnees betwixt two worlds. Mahwah, NJ: Lawrence Erlbaum.

Kasper, G. \& Roever, C. (2005). Pragmatics in second language learning. In E. Hinkel (Ed.), Handbook of Research in second language Teaching and Learning (v.1), (pp. 317-334). New Jersey: Lawrence Erlbaum Associates, İnc., Publishers.

Kasper, G. \& Rose, K. R. (2002). Pragmatic development in a second language. Michigan: Blackwell.

Mey, Jacob L. (2001). Pragmatics: An Introduction (2nd ed). Oxford/Malden, MA: Blackwell.

Michel, A. (1986). Down with stereotypes! Eliminating sexism from children's literature and school textbooks. Paris: UNESCO.

Mkuchu, S. G. V. (2004). Gender roles in textbooks as a function of hidden curriculum in Tanzania primary schools. Unpublished doctoral dissertation, University of South Africa.

Norton, P. B. (1995). Social identity, investment and language learning. TESOL Quarterly, 29, 9-31.

Pavlenko, A. \& Lantolf, J. P. (2000). Second language learning as participation and the (re)construction of selves. In J.P.Lantolf (Eds.) Sociocultural theory and second language learning (pp.155-177). New York : Oxford University Press.

Philips, S. U. (2004). Language and social inequality. A. Duranti (Ed.), Companion to linguistic anthropology. Blackwell: London.

Poulou, S.(1997). Sexism in the discourse roles of textbook dialogues. Language Learning Journal, 15, 68-73.

Salazar Campillo, P. (2007). Examining mitigation in requests: A focus on transcripts in ELT coursebooks. In E. Alcón Soler, \& M. P. Safont (Eds.), Intercultural Language Use and Language Learning (pp. 207222). The Netherlands: Springer.

Schimdt, R. (2001). Attention. In P. Robinson (Ed.), Cognition and second language instruction (pp. 3-33). New York: Cambridge University Press.

Tasmajian, D. (2002). Socialization skills acquired by elementary school children. Under-graduate Research Journal for the Human Sciences, 1. Retrieved May 02, 2012 from http://www.kon.org/urc/tasmajian.html.

TDK. (2005). Essential Turkish dictionary. Türk Dil Kurumu Yayını: Ankara, Turkey.

Thomas, J. (1983). Cross-cultural pragmatic failure. Applied Linguistics, 4(2), 91-112. 